\title{
1 \\ Analogue Nostalgia and the Aesthetics of Digital Remediation
}

\author{
Dominik Schrey
}

\section{Obsolescence and retro-cultures}

It has become a commonplace to describe the last decades as a period of unprecedented and ever-accelerating media technological transition and of increasingly mediated life environments. Our times have often been characterised as an era of planned obsolescence, turning yesterday's appraised new gadgets into today's decrepit devices and tomorrow's waste. Their disposability may even be 'one of the truly distinctive features of new media in our age', according to Jonathan Sterne (2007, p. 18). Moreover, even media formats with a strong tradition like the book (as a material object) or cinema (as a specific 'dispositif') are now perceived to be threatened by obsolescence and seem to be outpaced by their increasingly ephemeral digital successors. Referring to these correlating processes, science fiction writer Bruce Sterling proclaimed in 1995 that we live in 'the golden age of dead media' $(2008, p$. 80). It also seems to be a golden age of nostalgia for these allegedly 'dead media' that, in fact, continue to haunt a popular culture obsessed with its own past (Guffey, 2006; Reynolds, 2011). Jussi Parikka argues that retro-cultures 'seem to be as natural a part of the digital-culture landscape as highdefinition screen technology and super-fast broadband' (2012, p. 3). This distinct sense of nostalgia that Western societies have developed has to be understood as an integral aspect of our culture of preserving and storing. As Hartmut Böhme notes, in everything that is preserved and remembered they emphasise that which is still lost and forgotten, and thus create a deliberate emptiness (2000, p. 25). With this in mind, it seems important to consider the 'mediality' of nostalgia itself.

Based on a brief overview of this culture of (un)dead media, I will discuss one of the most recent manifestations of this general trend of 
nostalgia: the longing for what is assumed to be lost in the continuing process of digitisation that accounts for contemporary media culture's widespread romanticising and fetishising of analogue media. Symptoms of this 'analogue nostalgia' in its broadest sense can be found in every area of culture and society. For example, in 2012, the Academy for Motion Picture Arts and Sciences awarded the most Oscars to The Artist (Michel Hazanavicius, 2011) and Hugo (Martin Scorsese, 2011). Both of these films celebrate not only the artistic qualities of early cinema but also the celluloid filmstrip as its material basis, and what David Bordwell calls the 'Steampunk flavor' (2012, p. 7) of analogue film projection. Similar trends can be observed in the context of avantgarde art. Many of the most successful contemporary installation artists display a deep affection for outdated analogue media, and 'today, no exhibition is complete without some form of bulky, obsolete technology', as Claire Bishop writes in her broadly discussed article 'The Digital Divide' (2012, p. 436). In general, these retrospective celebrations of the analogue range from defiant denunciations of digital production tools (as practised most famously by artists like Tacita Dean) to the fetishised commodification of the analogue object (like the ubiquity of the analogue audio cassette as an icon on t-shirts, tote-bags and smartphone covers). Most pivotal for this context, however, are those works that quote certain characteristics typically associated with analogue inscription within digital media in a more or less self-reflexive fashion. In 2000, Laura Marks described this digital remediation of analogue aesthetics as 'analog nostalgia', although today the term is applied to a broader range of phenomena.

This chapter will be less interested in the technical differences between 'the analogue' and 'the digital' than in the affective attributes of these respective fields. Specifically, I will examine why aspects that were once considered as disadvantages or problems of analogue media are now appreciated enthusiastically. To investigate what causes this retrospective revaluation of analogue media's malfunctions and the specific noises they create, I will draw upon Sterne's questioning of the 'metaphysics of recording' (2006) and the 'double logic of remediation' as put forward by J. D. Bolter and Richard Grusin (2000). Based on a brief analysis of a scene from the contemporary TV series Californication (Showtime, 2007-2012), I will argue in conclusion that the phenomenon of 'analog nostalgia' (in Marks's sense of the term) embodies a return to the seventeenth and eighteenth centuries' fascination with ruins and its fragmentary aesthetics, which eventually led to the construction of artificial ruins. 


\section{The mediality of nostalgia}

Media can serve as a means of virtually accessing the past, and are thus an important resource for cultural memory. Consequently, they often establish the precondition for a nostalgic perspective on things past (and present). This nostalgia can be the content or style of media representation, and, beyond that, media themselves can become an object of nostalgia. In this case, the sentiment can be directed towards their specific medial constitution, their materiality, the aesthetics resulting from these factors, or all these combined: 'Our cultural memories are shaped not just by the production qualities of an era [...] but by subtle properties of the recording media themselves', as Reynolds (2011, p. 331) notes. This process, in turn, can then be reflected by media again, which is why nostalgia for outdated media technologies or their respective aesthetics can be regarded as a special case of self-reference in the media (Böhn, 2007).

Of course, the general phenomenon of nostalgia for outdated media is anything but new. According to Svetlana Boym, 'outbreaks of nostalgia often follow revolutions' (2001, p. xvi), which seems to be true not only in the context of politics she is referring to, but also in relation to mediahistorical periods of transition. In fact, nostalgia for seemingly obsolete modes of representation is a way of theorising changes in media with rich tradition and a surprisingly constant rhetoric. From the critique of writing in Plato's Phaedrus to the fears associated with the introduction of the printing press to the defensive reactions towards those new technologies of the nineteenth century that are now commonly referred to as 'analogue media' and the lamenting of the 'phantom world of television' (Anders, 1956), every media technological innovation can be, and has been, told as a nostalgic narrative of loss and decline (Serres, 2001). Evidently, the common denominator of these nostalgic narratives of media change is the fact that they assess the value of the new by the standards of the old, as Umberto Eco (1994) noted. While after almost 50 years Eco's analysis is still valid in many respects, it is important to stress the correlation between the flaws of apocalyptic media criticism he describes and the fact that new media always define themselves 'in relationship to earlier technologies of representation', as Bolter and Grusin assert (2000, p. 28). In their take on media history, ' $[w]$ hat is new about new media comes from the particular ways in which they refashion older media and the ways in which older media refashion themselves to answer the challenges of new media' (p. 15). 


\section{The metaphysics of recording}

This is not the place to delve into the complex conceptual histories of the terms 'analogue' and 'digital'. However, it seems important to emphasise two of the most important prerequisites for the phenomenon of analogue nostalgia. First, a semantic vagueness characterises the distinction between analogue and digital; the common media-historical approach makes this distinction 'into a matter of new and old' (Rosen, 2001, p. 303), while Western societies have developed a 'wider cultural situation where vintage is considered better than the new' (Parikka, 2012 , p. 3). Second, in order to understand media transition 'we must resist notions of media purity' and static definitions, as David Thorburn and Henry Jenkins $(2004$, p. 11) rightly point out. Yet, such pragmatic perspectives still seem scarce. Although often reduced to a simplistic dichotomy of mutually exclusive concepts, both terms, analogue and digital, have quite different implications and meanings in differing contexts. It is not only in their vernacular use that several overlapping semantic fields blur a precise understanding. The countless media-theoretical articles and books that have been written about the consequences of digitisation and the differences between analogue and digital representation in the last decades have fuelled the polysemy inherent in the terms and their distinction rather than offering clarification (Baudrillard, 2009). Film theorists of the 1990s and early 2000s, too, often described digitisation as a process of deprivation and disembodiment, a fundamental threat to film and photography as photochemical media (Sobchack, 1994). Based on idiosyncratic metaphors, like Roland Barthes's assertion that a 'sort of umbilical cord links the body of the photographed thing to my gaze' (2010, p. 81), the supposed continuous nature of analogue inscription and, especially, the direct connection between the representation and that which is represented were considered to be film's 'medium specificity' and were perceived as the very basis upon which film studies was built (Doane, 2007). In many accounts, the vaguely defined category of the analogue that gained contour mostly in contrast to its digital other was mistakenly identified completely with the indexical, as Tom Gunning (2007) and others have pointed out in recent years.

Most of the arguments put forward in this debate within film theory (and, to a certain degree, in media studies) had already been discussed in the context of audio recording and its question of 'fidelity' (Milner, 2010), yet these critical discourses have never intersected in a meaningful way. The forced displacement of analogue vinyl records and audio 
cassettes by the digital compact disc throughout the 1980s was one of the first moments when the scope of imminent media technological changes became evident to a broad public, creating an instant sense of nostalgia for the supplanted recording media. Many of the claims that the digital lacked something essential stem from this historical situation. As early as 1983, only a year after the official market introduction of the CD, an article entitled 'Digital Discontent' by David Lander was published in Rolling Stone magazine, stating: 'Maybe there's something in music that numbers and lasers can't translate' (1983, p. 88, cited in Chivers Yochim and Biddinger, 2008, p. 187). ${ }^{1}$

The concern behind this thought is obviously an epistemological one. In his trenchant article 'The Death and Life of Digital Audio' Sterne criticises this 'metaphysics of recording', specifically the idea that 'mediation is something that can be measured in terms of its distance from life' (Sterne, 2006, p. 338). According to Sterne, this notion originates in the age-old belief that a recording captures a certain amount of life and 'that as a recording traverses an ever larger number of technological steps, that quantity of life decreases, essentially moving it (and perhaps the listener) toward death' (p. 338). In their early days, those media now cherished as analogue were subject to the same criticism, as exemplified by Henri Bergson's Creative Evolution. Here, Bergson maintains that film, or 'cinematographic illusion', can never really capture the continuity of movement, as movement itself is always that which happens between the still images. Thus, in Bergson's perspective, movement essentially eludes recording, as it always 'slips through the interval' (1944, p. 334).

Sterne (2006) demonstrates that the same metaphysical argument is generally made regarding the discontinuity of digital inscription. Such arguments claim that the separate samples processed in binary code are merely 'simulations' of what they represent, hence missing the 'essence', the 'soul', the 'authenticity' or the 'aura' of the actual recorded sound. Sterne pleads for a re-evaluation of this question of 'life' in a recording as a 'social question, not an ontological or metaphysical one' (p. 339). Moreover, he proves that some analogue media, like the magnetic tape, are 'just as discontinuous as the 0 s and $1 \mathrm{~s}$ in digital storage' (p. 340f). Bolter and Grusin address the same desire for authenticity as part of a complex and seemingly contradictory double logic by assuming a discourse-analytical perspective. For them, one of the driving forces of media history is the desire for immediacy or the 'transparent presentation of the real' (2000, p. 21). This desire finds expression in media's attempt to erase all indicators of mediation ${ }^{2}$ and present their representations as 'life itself' (or, at least, as a direct window onto it). At the 
same time, though, there is another tendency working in the opposite direction. The logic of hypermediacy enjoys the opacity of representation and highlights or even multiplies the signs of mediation. These two cultural logics of immediacy and hypermediacy do not only coexist; they are mutually dependent. Approached from a social or psychological perspective, it becomes evident that both logics share an 'appeal to authenticity of experience' (p. 71) that is socially constructed. In consequence, even the 'excess of media' (p. 53) can become an authentic experience; hypermediacy can thus become a strategy to achieve immediacy. This seemingly paradoxical relationship can be illustrated with a famous quotation from British radio pioneer John Peel: 'Somebody was trying to tell me that CDs are better than vinyl because they don't have any surface noise. I said, "Listen, mate, life has surface noise", (Chassanoff, 2012). In this perspective, the specific signs of mediation that seem to distract from the immediacy of the recorded sound counter-intuitively create the authentic experience in the first place.

This reversal of the common logic of recording is characteristic of analogue nostalgia. In this context, Thomas Levin notes:

In the age of digital recording and playback, the sound of error has changed significantly $[\ldots]$ : The moment of the scratch is no longer the signal of malfunction but is instead the almost nostalgic trace of a bygone era of mechanical reproducibility, one can say that it has become auratic, and as such it suddenly becomes available for aesthetic practices of all sorts.

(1999, p. 162)

These aesthetic practices, however, can be remediated and appropriated in digital media to simulate or mimic this notion of an authentic or 'auratic' experience, as I intend to illustrate with the help of a scene from the recent TV series Californication in which the hitherto described discourses are neatly interwoven.

\section{An analogue guy in a digital world}

In an early episode of the series, the protagonist, troubled novelist and playboy Hank Moody, is shopping for groceries when he meets a woman who remains nameless throughout the episode and is only addressed as 'surfer girl' in the DVD's liner notes. As is typical of the series, they end up in Moody's apartment after a short and rather trivial conversation, sitting on the floor and smoking marijuana while listening to the writer's 
collection of old vinyl records. In this situation, the following dialogue unfolds:

Surfer Girl: 'I fucking love vinyl.'

Hank Moody: 'Yeah, it just sounds better. It's warmer, right? It's just human.'

Surfer Girl: 'You're just an analog guy in a digital world, aren't you?'

This highly clichéd scene encapsulates the basic concept of Californication. The series' appeal is based on the conflict between the 'old/authentic' and the 'new/superficial', situating its protagonist as an anachronistic 'last of his kind' character. Most of Hank Moody's key characteristics could be described as symptoms of a rather serious adaptive disorder, yet throughout the series he is depicted as irresistibly charming and as a stubborn and nostalgic romantic. Not only does he prefer his music to be played from vinyl records, but he also writes his books on an old typewriter instead of a computer. Of course, this affection for almost obsolescent media technology mirrors his equally obsessive clinging to outdated concepts and values like romantic love and artistic authenticity. He is tormented by the superficiality of Los Angeles and its entertainment industry, which turned his highbrow novel into a silly 'rom-com', and he is homesick for an idealised New York that apparently exists only in the past tense of fond memories, thus seeming ineffably remote. Hank Moody is the prime example of what Mark Desrosiers once called the 'R. Crumb Effect': 'when modernity gets you down, you can put yourself on the cutting edge by fetishizing ancient styles and technologies, and your antithetical influence will start making its mark on popular tastes' (2002).

To underline its nostalgia narrative, Californication relies heavily on the aesthetics of analogue film, which becomes particularly evident in the opening credits of the series. In a little less than a minute, the viewer is presented with the whole range of analogue artefacts (Flückiger, 2008, pp. 334-356), or typical flaws of decaying film stock. In the credit scene, the image looks dirty and gritty, laden with scratches and visible splices. A tattered grunge frame with rounded corners limits the picture as it would in an old $8 \mathrm{~mm}$ home movie. The film's grain is heavily visible, and, in some of the shots, the emulsion seems to be on the verge of dissolution. The perforation of the filmstrip, as well as the black intervals between frames, is repeatedly made visible. Additionally, numerous flash frames and lens flares emphasise the analogue nature of the footage. At first glance, the shots seem to represent Hank 
Moody's memories of 'better' times, shot in a home video style to signify their 'pastness' (see also Chapter 2 in this volume). The shots are obviously set in LA, though, and the same style is repeated in the frequent interludes that serve the narrative purpose of connecting discontinuous scenes.

Surprisingly, Californication is shot completely with digital cameras; only the pilot was filmed in $35 \mathrm{~mm}$, but this first episode did not yet feature the opening credit scene (Caranicas, 2011). All the described analogue artefacts were thus added digitally in the post-production process, proving Lev Manovich's assertion that the classic film look acquired 'a truly fetishist status' (1996, p. 58) in digital cinema. In fact, there are vendors like CineGrain.com who sell footage of raw analogue glitches for personal or professional use in collections ranging from $\$ 300$ to $\$ 3000$, advertising their products with phrases like the following: 'A film collection worn by time and too many projector changes. Here's the sought after looks for the messed up and scratched up, the tattered and dishevelled. Broken has never looked so beautiful.'

\section{Analogue nostalgia and the aesthetics of virtual ruins}

The term 'analog nostalgia' was originally coined to address aesthetic practices exactly like these. It appears for the first time in a chapter of Marks's book (2002); seven years later it reappears in Rombes's Cinema in the Digital Age (2009), though without an explicit reference to Marks. For Marks, analogue nostalgia expresses a 'desire for indexicality' and 'a retrospective fondness for the "problems" of decay and generational loss that analog video posed' (p. 152). Thus, in her perspective, the phenomenon is not about the refusal of digital technologies, but exclusively about the digital remediation of analogue aesthetics within the digital. To put it in terms of communication theory, analogue nostalgia is directed towards the noise, not the signal. In the broadest sense, it operates as a strategy of re-enchanting an object through aesthetic de-familiarisation as it is characterised by deliberate imperfection:

In the high fidelity medium of digital video, where each generation can be as imperviously perfect as the one before, artists are importing images of electronic dropout and decay, 'TV snow' and the random colours of unrecorded tape, in a sort of longing for analog physicality. Interestingly, analog nostalgia seems especially prevalent among works by students who started learning video production when it was fully digital. (p. 152f) 
Rombes does not explicitly link his only sketchily defined concept of analogue nostalgia to indexicality, but for him, too, there is 'a tendency in digital media $[\ldots]$ to reassert imperfection, flaws, an aura of human mistakes to counterbalance the logic of perfection that pervades the digital' $(2009$, p. 2). Sometimes, Rombes's text itself verges on a polemical and nostalgic manifesto, for example when he concludes his book with these sentences: 'In the end, it is the mistakes, the errors that we assert in the face of the code that keeps it from consuming us with its purity. Mistakes must be our answer to the machines of perfection that we ourselves have built' (2009, p. 156). In this regard, analogue nostalgia as an aesthetic practice is the paradoxical attempt to preserve decay and plan contingency.

'What is lost in the move to the digital is the imprint of time, the visible degradation of the image', writes Mary Anne Doane (2007, p. 117f), a claim that is intentionally or unintentionally reminiscent of Benjamin's famous description of the aura withering in the age of technological reproducibility (2008, p. 22). Assigning an almost organic quality to analogue media, David N. Rodowick notes that 'the material basis of film is a chemically encoded process of entropy' (2007, p. 20). From this perspective, analogue media do not merely contain a certain amount of life, as discussed in the context of the 'metaphysics of recording'; they even share certain essential qualities with it. In fact, analogue media age, and they show distinct signs of decay the older they get; each playing of a vinyl record or a celluloid film expedites its self-liquidation. This process leads to the traces of usage that typically appear exactly at those moments which were often replayed or rewound. This fact might be of great importance for a deeper understanding of analogue nostalgia.

In an article on cinephilia, Robnik writes that analogue 'rental videos confront you with traces, ruined images, left behind by someone else's fascination by a moment' $(2005$, p. 59). For him, the analogue's malfunctions constitute 'textual ruins' and are thus more than just indicators of age, as they can also be understood as traces of appreciation or pleasure. ${ }^{3}$ When these traces of use are digitally simulated, we abolish the uncanny fact that in organic life - as well as in analogue media the process of aging irretrievably leads to death or complete dysfunction, respectively. Analogue nostalgia simulates a process of aging that has not happened yet, and never will happen (at least, not in the form that is simulated). This condition is analogous to the artificial ruins of the seventeenth and eighteenth centuries, as it involves the artificial, or, rather, virtual, ruins of the digital age. However, these ruins are no longer 'signifiers of absence', as Böhme (1989) once defined the lure of 
ancient ruins. On the contrary, the purpose of this digitally simulated analogue decay seems to be the signification of presence: as it simulates exactly the life or 'soul' that the digital was always accused of lacking.

\section{Notes}

1. Certainly not by mere coincidence, the same year also saw the release of Herbie Hancock's Rockit, the first mainstream music title to feature scratching as an artistic practice. Speaking with Rosalind Krauss (1999), one could call this the 'redemptive role' of the threat of obsolescence that leads to an artistic reinvention of the medium and the ways in which it can be deployed.

2. In this context, it should be noted that a similar claim can be found in Walter Benjamin's famous Artwork essay and its description of the 'vision of immediate reality' as 'the Blue Flower in the land of technology' (2008, p. 35). The 'Blue Flower' as a pivotal symbol of German Romanticism is the idealisation of that which cannot be obtained, something that is always already lost and exists only in longing desire.

3. The best illustration for this assumption is Quentin Tarantino's 2007 film Death Proof, where he playfully suggests that the climactic moments of a lapdance scene might have been cut out of the film by the projectionist for his own collection, leaving the actual viewers of the film with a 'textual ruin' (Schrey, 2010, p. 189).

\section{References}

Anders, G. (1956) 'The Phantom World of TV'. Dissent, 3, pp. 14-24.

Barthes, R. (2010) Camera Lucida. Reflections on Photography. Translated by Richard Howard. New York: Hill and Wang.

Baudrillard, J. (2009) Why Hasn't Everything Already Disappeared? Translated by Chris Turner. London, New York: Seagull Books.

Benjamin, W. (2008) 'The Work of Art in the Age of its Technological Reproducibility' (second version), in M. W. Jennings, B. Doherty and T. Y. Levin (eds) The Work of Art in the Age of its Technological Reproducibility, and Other Writings on Media. Cambridge, MA; London: Belknap Press of Harvard University Press, pp. 19-55.

Bergson, H. (1944) Creative Evolution. Translated by Arthur Mitchell. New York, NY: Modern Library.

Bishop, C. (2012) 'Digital Divide'. Artforum, September 2012, pp. 435-441.

Böhme, H. (1989) 'Die Ästhetik der Ruinen', in D. Kamper and C. Wulf (eds) Der Schein des Schönen. Göttingen: Steidl, pp. 287-304.

Böhme, H. (2000) 'Der Wettstreit der Medien im Andenken der Toten', in H. Belting and D. Kamper (eds) Der zweite Blick. Bildgeschichte und Bildreflexion. München: Fink, pp. 23-43.

Böhn, A. (2007) 'Nostalgia of the Media/in the Media', in W. Nöth and N. Bishara (eds) Self-Reference in the Media. Berlin, New York: Mouton de Gruyter, pp. 143-153.

Bolter, J. D. and Grusin, R. (2000) Remediation. Understanding New Media. Cambridge, MA, London: MIT Press. 
Bordwell, D. (2012) Pandora's Digital Box. Film, Files, and the Future of Movies. Madison, WI: Irvington Way Institute Press.

Boym, S. (2001) The Future of Nostalgia. New York: Basic Books.

Caranicas, P. (2011) “"Californication” Leaves no Trail of Tape. Arri Alexa Allows Show to Shoot on Reusable Memory Cards'. http://www.variety.com/article/ VR1118040091 (accessed 17 December 2012).

Chassanoff, A. (2012) 'Life has Surface Noise. (Further) Ruminations on the Record'. http://hastac.org/blogs/achass/2012/01/23/life-has-surface-noisefurther-ruminations-record (accessed 24 June 2013).

Chivers Yochim, E. and Biddinger, M. (2008) " It kind of gives you that vintage feel". Vinyl Records and the Trope of Death'. Media, Culture \& Society, 30(2), pp. 183-195.

Desrosiers, M. (2002) 'Maim that Tune. The Moldy Peaches and the Apotheosis of Lo-Fi'. http://www.popmatters.com/pm/column/desrosiers020306/ (accessed 17 December 2012).

Doane, M. A. (2007) 'The Indexical and the Concept of Medium Specificity'. differences. A Journal of Feminist Cultural Studies, 18(1), pp. 128-152.

Eco, U. (1994) Apocalypse Postponed. Translated by Robert Lumley. Bloomington and London: BFI.

Flückiger, B. (2008) Visual Effects: Filmbilder aus dem Computer. Marburg: Schüren. Guffey, E. E. (2006) Retro: The Culture of Revival. London: Reaktion.

Gunning, T. (2007) 'Moving Away from the Index: Cinema and the Impression of Reality'. differences. A Journal of Feminist Cultural Studies, 18(1), pp. 29-52.

Krauss, R. E. (1999) 'Reinventing the Medium'. Critical Inquiry, 25(2), pp. 289-305.

Levin, T. Y. (1999) 'Indexicality Concrète: The Aesthetic Politics of Christian Marclay's Grammophonia'. Parkett, (56), pp. 162-169.

Manovich, L. (1996) 'The Paradoxes of Digital Photography', in H. von Amelunxen, S. Iglhaut and F. Rötzer (eds) Photography After Photography. Memory and Representation in the Digital Age. Dresden: GB Arts, pp. 57-65.

Marks, L. U. (2002) Touch. Sensuous Theory and Multisensory Media. Minneapolis, $\mathrm{MN}$ : University of Minnesota Press.

Milner, G. (2010) Perfecting Sound Forever. The Story of Recorded Music. London: Granta.

Parikka, J. (2012) What Is Media Archaeology? Cambridge UK, Malden, MA: Polity. Reynolds, S. (2011) Retromania. Pop Culture's Addiction to Its Own Past. New York: Faber \& Faber.

Robnik, D. (2005) 'Mass Memories of Movies. Cinephilia as Norm and Narrative in Blockbuster Culture', in M. de Valck and M. Hagener (eds) Cinephilia. Movies, Love and Memory. Amsterdam: Amsterdam University Press (Film Culture in Transition), pp. 55-64.

Rodowick, D. N. (2007) The Virtual Life of Film. Cambridge, MA and London: Harvard University Press.

Rombes, N. (2009) Cinema in the Digital Age. London, New York: Wallflower Press. Rosen, P. (2001) Change Mummified. Cinema, Historicity, Theory. Minneapolis, MN: University of Minnesota Press.

Schrey, D. (2010) 'Mediennostalgie und Cinephilie im GrindhouseDoublefeature', in A. Böhn and K. Möser (eds) Techniknostalgie und Retrotechnologie. Karlsruhe: KIT Scientific Publishing, pp. 183-195. 
Serres, M. (2001) 'New Technologies'. Mousaion, 19(1), pp. 25-34.

Sobchack, V. (1994) 'The Scene of the Screen. Envisioning Cinematic and Electronic "Presence" ', in H. U. Gumbrecht and K. Ludwig Pfeiffer (eds) Materialities of Communication. Stanford, CA: Stanford University Press, pp. 83-106.

Sterling, B. (2008) 'The Life and Death of Media', in P. D. Miller (ed.) Sound Unbound. Sampling Digital Music and Culture. Cambridge, MA and London: MIT Press, pp. 73-82.

Sterne, J. (2006) 'The Death and Life of Digital Audio'. Interdisciplinary Science Reviews, 31(4), pp. 338-348.

Sterne, J. (2007) 'Out with the Trash. On the Future of New Media', in C. R. Acland (ed.) Residual Media. Minneapolis: University of Minnesota Press, pp. 16-31.

Thorburn, D. and Jenkins, H. (2004) Rethinking Media Change. The Aesthetics of Transition. Cambridge, MA and London: MIT Press, pp. 1-18. 


\section{Media and Nostalgia \\ Yearning for the Past, Present and Future}

Edited by

Katharina Niemeyer

The French Press Institute/CARISM, Pantheon-Assas University, Paris 2, France

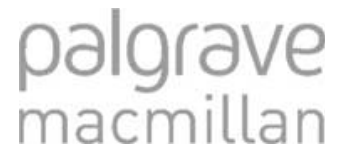




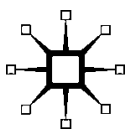

Introduction, selection and editorial matter (c) Katharina Niemeyer 2014 Individual chapters () Respective authors 2014 Cover photograph (๑) Marlène Dorgny (textile and graphic designer) Softcover reprint of the hardcover 1st edition 2014 978-1-137-37587-2 All rights reserved. No reproduction, copy or transmission of this publication may be made without written permission.

No portion of this publication may be reproduced, copied or transmitted save with written permission or in accordance with the provisions of the Copyright, Designs and Patents Act 1988, or under the terms of any licence permitting limited copying issued by the Copyright Licensing Agency, Saffron House, 6-10 Kirby Street, London EC1N 8TS.

Any person who does any unauthorized act in relation to this publication may be liable to criminal prosecution and civil claims for damages.

The authors have asserted their rights to be identified as the authors of this work in accordance with the Copyright, Designs and Patents Act 1988.

First published 2014 by

PALGRAVE MACMILLAN

Palgrave Macmillan in the UK is an imprint of Macmillan Publishers Limited, registered in England, company number 785998, of Houndmills, Basingstoke, Hampshire RG21 6XS.

Palgrave Macmillan in the US is a division of St Martin's Press LLC, 175 Fifth Avenue, New York, NY 10010.

Palgrave Macmillan is the global academic imprint of the above companies and has companies and representatives throughout the world.

Palgrave ${ }^{\circledR}$ and Macmillan ${ }^{\circledR}$ are registered trademarks in the United States, the United Kingdom, Europe and other countries.

ISBN 978-1-349-47750-0

ISBN 978-1-137-37588-9 (eBook)

DOI $10.1057 / 9781137375889$

This book is printed on paper suitable for recycling and made from fully managed and sustained forest sources. Logging, pulping and manufacturing processes are expected to conform to the environmental regulations of the country of origin.

A catalogue record for this book is available from the British Library.

A catalog record for this book is available from the Library of Congress. 


\section{Contents}

List of Figures vii

Acknowledgements viii

Notes on Contributors $\quad$ ix

Introduction: Media and Nostalgia 1

Katharina Niemeyer

Part I Analogue Nostalgias

1 Analogue Nostalgia and the Aesthetics of Digital Remediation

Dominik Schrey

2 Homesick for Aged Home Movies: Why Do We Shoot Contemporary Family Videos in Old-Fashioned Ways?

Giuseppina Sapio

3 The Instant Past: Nostalgia and Digital Retro Photography Gil Bartholeyns

4 Retromania: Crisis of the Progressive Ideal and Pop Music Spectrality

Maël Guesdon and Philippe Le Guern

\section{Part II Exploited Nostalgias}

5 Retrotyping and the Marketing of Nostalgia Michael Pickering and Emily Keightley

6 Anti-nostalgia in Citroën's Advertising Campaign Emmanuelle Fantin

7 Networks as Media for Nostalgia in an Organisational Context

Thibaut Bardon, Emmanuel Josserand and Florence Villesèche

8 Media and the Closure of the Memory Boom Andrew Hoskins 
vi Contents

\section{Part III Screened Nostalgias}

9 Nostalgia Is Not What It Used to Be: Serial Nostalgia and Nostalgic Television Series

Katharina Niemeyer and Daniela Wentz

10 AMC's Mad Men and the Politics of Nostalgia David Pierson

11 The Television Channel ARTE as a Time Machine and Matrix for European Identity Aline Hartemann

12 Nostalgia, Tinted Memories and Cinematic Historiography: On Otto Preminger's Bonjour Tristesse (1958)

Ute Holl

\section{Part IV Creative Nostalgias}

13 Creative Nostalgia for an Imagined Better Future: Il treno del Sud by the Migrant Filmmaker Alvaro Bizzarri Morena La Barba

14 Nostalgia and Postcolonial Utopia in Senghor's Négritude Nadia Yala Kisukidi

15 Impossible Nostalgia Itzhak Goldberg

16 Journeys through the Past: Contempt, Nostalgia, Enigma John Potts

Poetic Transfer of a (Serious) Situation

Marine Baudrillard

Index 